\title{
IMPROVEMENT OF SEED GERMINATION BEHAVIOUR IN PHYLLANTHUS AMARUS BY ACID AND MECHANICAL SCARIFICATION PRETREATMENTS
}

\author{
Meenu Gehlot and Pawan K. Kasera* \\ Laboratory of Plant Ecology, Department of Botany \\ Jai Narain Vyas University, Jodhpur 342 033, India \\ *Email: jnvupkkasera@yahoo.co.in
}

\begin{abstract}
Phyllanthus amarus (Bhui-Aanwalaa: Family: Euphorbiaceae) is considered to be the most important medicinal plant of the Indian Thar desert. The present article deals with its seed morphological parameters, seed output, reproductive capacity (RC), germination behavior, seedling growth, root: shoot ratio (R/S ratio), germination value (GV) and vigour index (VI) in fresh and one-year-old seeds under controlled laboratory conditions. Results revealed that 73.33 and $60 \%$ germination was observed in fresh and one-year-old seeds as compared to the control (20\% in fresh; while $36.67 \%$ in one-year-old seeds) after providing mechanical + conc. $\mathrm{H}_{2} \mathrm{SO}_{4}$ scarification for 2 and 1 min, respectively. The maximum VI and $\mathrm{GV}$ were obtained in mechanical + conc. $\mathrm{H}_{2} \mathrm{SO}_{4}$ scarification for 2 min pretreatments in fresh seeds.
\end{abstract}

Key words: Phyllanthus amarus, acid scarification, seed germination, seedling growth.

\section{INTRODUCTION}

Phyllanthus amarus Schum. and Thonn. is distributed throughout the hotter parts of India, particularly on cultivated land upto $1000 \mathrm{~m}$ (Khare 2007). Aerial parts exhibited marked antiinflammatory properties which suggest that lignans are the main active principles responsible for the traditional application of this plant for the inflammatory complaints (Kassuya et al. 2005). Whole plants have been used in traditional medicine in Central and South America and Asia (including India and Indonesia) for the treatment of jaundice, asthma, hepatitis, malaria and for its diuretic, anti-viral and hypoglycemic properties (Calixto et al. 1998).
Seed germination and early seedling growth are considered the most critical phases for establishment of any species and thus it is often emphasized that tolerance of seeds to various stresses during germination should be determined. Seed germination is an important stage of plant growth which is controlled by environmental factors as well as by physiological processes (Finch-Savage and Leubner-Metzger 2006). Dormancy of seed, especially those of arid zone plants are biologically significant in speeding or delaying germination until the environment is favourable for the development and establishment of seedlings. Delayed germination is of great significance, especially in an arid zone, where the 
conditions are unflattering and unpleasant for normal growth and development of plants for long periods (Sen 1977). Pretreatments such as concentrated sulphuric acid, mechanical scarification, growth regulators, nitrates, etc. are likely to facilitate water imbibitions and gaseous exchange, which ultimately lead to higher percentage besides speedy germination depicted as germination value $(\mathrm{GV})$. Thus in the present studies, an attempt has been made to study the various morphological parameters of seeds such as weight, volume, size, density, reproductive capacity and effects of acid and mechanical scarifications for breaking the hard seed coat dormancy as well as enhancement of germination and seedling growth parameters under controlled laboratory conditions in $P$. amarus.

\section{MATERIALS AND METHODS}

The mature fruits of $P$. amarus were collected from Ratanada Police Lines, Jodhpur ( $8 \mathrm{~km}$ away in north-east direction from the University Campus) during August-October 2008-2009 and 2009-2010. The mature fruits were cleaned and stored (at room temperature) in plastic containers with parad tablets/BHC powder to protect them from insects. The shape and colour of seeds were observed under dissecting microscope. The seed size (length and breadth) was measured with the help of vernier caliper. The weight of 100 seeds was taken with electronic balance. The volume of 100 seeds was calculated using water displacement method. Seed density was measured by using following formula:

$$
\text { Seed density }\left(\mathrm{g} \mathrm{cc}^{-1}\right)=\frac{\text { Seed weight }(\mathrm{g})}{\text { Seed volume }(\mathrm{cc})}
$$

All parameters were taken in triplicate and confirmed twice.

The seed viability in freshly harvested and after 12 months of storage period was tested as per Porter et al. (1947). The seed output and reproductive capacity (RC) were calculated by using the formula given by Salisbury (1942).

$\mathrm{RC}=\frac{\text { Average seed output } \times \text { Average germination }(\%)}{100}$

Seeds germination behaviour was studied in fresh and one-year-old seeds. For germination studies, seeds were placed in sterilized petri dishes lined with single layer of filter paper, moistened with distilled water as and when needed. The experimental petri dish contained 10 seeds in triplicate and the experiments were repeated twice. The germination experiments were performed in alternate white light and dark (12 h) obtained from 3 fluorescent tubes of 40 watts each fitted at a height of half meter from the petri dishes (1000 lux) at $28^{\circ} \mathrm{C}$ in seed germinator. After 10 days of setting the experiments, seed germination $(\%)$ and root and shoot length of seedlings were measured.

Hard seed coat dormancy was prevalent in this species, so for its removal seeds were pretreated with conc. $\mathrm{H}_{2} \mathrm{SO}_{4}$ acid scarification (1 and $2 \mathrm{~min}$ ) and mechanical + conc. $\mathrm{H}_{2} \mathrm{SO}_{4}$ acid scarifications (1 and $2 \mathrm{~min}$ ) and then kept under running tap water for 3-4 h. Afterwards, pretreated seeds were kept for germination studies. Germination values of seeds were calculated for each treatment as per Czabator (1962):

$\mathrm{GV}=\mathrm{PV} \times \mathrm{MDG}$

Where, $\mathrm{PV}=$ Peak value of germination; and MDG $=$ Mean daily germination

$\mathrm{PV}$ is calculated with the following formula:

$$
\begin{gathered}
\mathrm{PV}=\frac{\text { Final germination percentage }}{\text { No. of days that took to reach the peak germination }} \\
\text { MDG is calculated as follows: } \\
\mathrm{MDG}=\frac{\text { Total germination percentage }}{\text { Total number of days }}
\end{gathered}
$$

The vigour index (VI) was derived from the formula given by Abdul-Baki and Anderson (1973), which is as follows: 
VI $=$ Percentage of germination $\times$ Seedling length $(\mathrm{cm})$

Where, seedling lengths are the sum of root and shoot lengths.

The mean values of data obtained from six replicates during the both years for each parameter were executed using CRD design and statistically analyzed by one way ANOVA as suggested by Gomez and Gomez (1984).

\section{RESULTS}

The fresh seeds of P. amarus exhibited $100 \%$ viability, which reduced to $70 \%$ after one year of storage, indicating decreasing in viability after storage. The seeds were blackish-brown coloured, kidney shaped, $1.089 \mathrm{~mm}$ long and $0.591 \mathrm{~mm}$ broad having $0.039 \mathrm{~g} \mathrm{cc}^{-1}$ density. The seed output and reproductive capacity were 9174.889 and 2568, respectively (Table 1).

It is evident from Table 2 that 20 and $36.67 \%$ seeds germinated in control experiments in fresh and one-year-old seeds, respectively. 73.33 and $60 \%$ germination was observed in fresh and oneyear-old seeds after providing mechanical + conc. $\mathrm{H}_{2} \mathrm{SO}_{4}$ scarifications for 2 and $1 \mathrm{~min}$, respectively. The maximum length for root and shoot in seedlings from fresh seeds were observed in control as compared to other pretreatments, whereas in one-year-old seeds these values were maximum in conc. $\mathrm{H}_{2} \mathrm{SO}_{4}$ for $1 \mathrm{~min}$ and mechanical + conc. $\mathrm{H}_{2} \mathrm{SO}_{4}$ scarifications for $1 \mathrm{~min}$ pretreatments, respectively. The highest R/S ratio in fresh (1.009) and one-year-old seeds (0.993) was observed in conc. $\mathrm{H}_{2} \mathrm{SO}_{4}$ for $1 \mathrm{~min}$ and mechanical + acid scarifications for $2 \mathrm{~min}$ pretreatments, respectively. The maximum VI (260.248) and GV (268.864) were obtained in mechanical + conc. $\mathrm{H}_{2} \mathrm{SO}_{4}$ scarifications for $2 \mathrm{~min}$ in fresh seeds.

Table 1. Morphological parameters of $\boldsymbol{P}$. amarus seeds.

\begin{tabular}{ll}
\hline Parameters & Values \\
\hline Colour & Blackish-brown \\
Shape & Kidney \\
Length (mm) & $1.089 \pm 0.064$ \\
Breadth (mm) & $0.591 \pm 0.039$ \\
Weight of 100 seeds $(\mathrm{g})$ & $0.017 \pm 0.001$ \\
Volume of 100 seeds $(\mathrm{cc})^{-1}$ & $0.49 \pm 0.071$ \\
Density (g cc $\left.{ }^{-1}\right)$ & $0.039 \pm 0.006$ \\
Seed output plant & -1 \\
Reproductive capacity & $2568.00 \pm 181.05$ \\
\hline
\end{tabular}

$\pm=$ Standard deviation.

The data were significant at $95 \%$ probability level, except for root and shoot lengths in both types of seeds, germination percentage in one-yearold seeds and R/S ratio and VI in fresh seeds, which were non-significant.

Table 2. Effect of different pretreatments on various parameters in fresh and one-year-old seeds of $P$. amarus.

\begin{tabular}{|c|c|c|c|c|c|c|c|c|c|c|c|c|c|}
\hline \multirow[t]{3}{*}{ Treatments } & \multirow{3}{*}{$\begin{array}{c}\text { Duration } \\
\text { (min.) }\end{array}$} & \multirow{2}{*}{\multicolumn{2}{|c|}{ Germination (\%) }} & \multicolumn{4}{|c|}{ Seedling growth $(\mathbf{c m})$} & \multicolumn{2}{|c|}{ R/S Ratio } & \multicolumn{2}{|c|}{ VI } & \multicolumn{2}{|c|}{ GV } \\
\hline & & & & \multicolumn{2}{|c|}{ Root length } & \multicolumn{2}{|c|}{ Shoot length } & \multirow[b]{2}{*}{ Fresh } & \multirow[b]{2}{*}{ Old } & \multirow[b]{2}{*}{ Fresh } & \multirow[b]{2}{*}{ Old } & \multirow[b]{2}{*}{ Fresh } & \multirow[b]{2}{*}{ Old } \\
\hline & & Fresh & Old & Fresh & Old & Fresh & Old & & & & & & \\
\hline Control & & 20.00 & 36.67 & 1.90 & 1.563 & 2.033 & 1.59 & 0.934 & 0.983 & 78.66 & 115.62 & 13.332 & 67.234 \\
\hline Conc. & 1 & 40.00 & 40.00 & 1.85 & 1.575 & 1.833 & 1.591 & 1.009 & 0.989 & 147.32 & 126.64 & 53.332 & 80.00 \\
\hline $\mathrm{H}_{2} \mathrm{SO}_{4}(\mathrm{~min})$ & 2 & 56.67 & 53.33 & 1.276 & 1.262 & 1.605 & 1.462 & 0.795 & 0.863 & 163.266 & 145.27 & 80.284 & 142.124 \\
\hline MS & 1 & 43.33 & 60.00 & 1.215 & 1.277 & 1.669 & 1.594 & 0.727 & 0.801 & 124.963 & 172.26 & 62.582 & 180.00 \\
\hline $\begin{array}{l}+ \text { Conc. } \\
\mathrm{H}_{2} \mathrm{SO}_{4} \text { (min) }\end{array}$ & 2 & 73.33 & 40.00 & 1.731 & 1.391 & 1.818 & 1.40 & 0.952 & 0.993 & 260.248 & 111.64 & 268.864 & 80.00 \\
\hline $\mathrm{CD}$ & & $29.370 *$ & $18.511^{\mathrm{ns}}$ & $0.596^{\text {ns }}$ & $0.435^{\text {ns }}$ & $0.648^{\text {ns }}$ & $0.370^{\text {ns }}$ & $0.554^{\text {ns }}$ & $0.153 *$ & $197.771^{\mathrm{ns}}$ & $1.653 *$ & $1.952 *$ & $5.386^{*}$ \\
\hline
\end{tabular}

MS = Mechanical scarification; R/S ratio= Root/shoot length; VI= Vigour Index; and GV= Germination value. $*=$ Significant at $(\mathrm{P}<0.05)$ level; and ns= non-significant. 


\section{DISCUSSION}

Studies of seed morphology are considered essential to understand its variability, which is an important adaptation in the life of desert plants. It has an ecological significance for their long term perpetuation in the area as well as introduction to new areas. Pretreatments significantly improve the final germination percentage and germination rate when compared to untreated seeds (Tiryaki 2006). The germination regulating mechanisms are variable in different species and even the individuals of the same plant species. Chemical scarification renders the seed coat permeable to water and induced germination (Mutha et al. 2004). Acid treatment can break seed dormancy for a number of species. The highest germination in Cenchrus ciliaris was achieved when seeds were soaked in conc. $\mathrm{H}_{2} \mathrm{SO}_{4}$ for 4 mins and prolonged soaking burnt seeds completely as reported by Bhattarai et al. (2008). Bhanuprakash et al. (2004) reported that scarification with $75 \%$ conc. $\mathrm{H}_{2} \mathrm{SO}_{4}$ for 15 mins gave highest germination percentage, seedling length and vigour index in Rosa sp. Gupta et al. (2004) reported maximum vigour index in Thespesia populnea when the seeds were pretreated with conc. $\mathrm{H}_{2} \mathrm{SO}_{4}$ for 20 mins. Verma and Kasera (2006) reported maximum (70\%) germination in Sida cordifolia after 15 mins of conc. $\mathrm{H}_{2} \mathrm{SO}_{4}$ pretreatment.

Mechanical scarification also plays an important role in overcoming hard seed coat dormancy. Gupta (2001) observed 80\% germination in Abelmoschus moschatus after mechanical scarification. Saharan et al. (2001) observed 80 and $100 \%$ germination with conc. $\mathrm{H}_{2} \mathrm{SO}_{4}$ for 25 mins and mechanical scarification, respectively in Evolvulus alsinoides.

In the present studies, fresh seeds of $P$. amarus showed maximum values of seed germination, VI and GV when subjected to mechanical scarification along with 2 min of conc. $\mathrm{H}_{2} \mathrm{SO}_{4}$ pretreatments. The observations recorded by above-mentioned researchers also confirm the present results. So the present study concludes that for fast multiplication of this plant species, seeds should be pretreated with mechanical scarification along with 2 min of conc. $\mathrm{H}_{2} \mathrm{SO}_{4}$ pretreatments.

\section{ACKNOWLEDGEMENTS}

Thanks to the Professor and Head, Department of Botany, J.N. Vyas University, Jodhpur for providing necessary facilities. The authors are also grateful to Dr. David N. Sen [Professor and Head (Retired), Department of Botany, J.N. Vyas University, Jodhpur] for valuable suggestions and guidance in improvement of this article.

\section{REFERENCES}

Abdul-Baki, A.A. and J.D. Anderson. 1973. Vigour determination in soybean seed by multiple criteria. Crop Sci. 13:630-633.

Bhanuprakash, K., H.S. Tejaswini, Yogeesha and L.B. Naik. 2004. Effect of scarification and gibberellic acid on breaking dormancy of rose seeds. Seed Research 32:105-107.

Bhattarai, S.P., J. Fox and Y. Gyasi-Agyei. 2008. Enhancing buffel grass seed germination by acid treatment for rapid vegetation establishment on railway batters. J. Arid Environ. 72:255-262.

Calixto, J.B., A.R.S. Santos, V.C. Filho and R.A. Tunes. 1998. A review of the plants of the genus Phyllanthus: Their chemistry, pharmacology and therapeutic potential. $J$. Med. Biol. Res. 31:225-258.

Czabator, F.J. 1962. Germination value: An index combining speed and completeness of pine seed germination. Forest Sci. 8:386-396. 
Finch-Savage, W.E. and G. Leubner-Metzger. 2006. Seed dormancy and control of germination. New Phytologist 17:501-523.

Gomez, K.A. and A.A. Gomez. 1984. Statistical Procedures for Agricultural Research. Second Edition. New York: John Wiley and Sons.

Gupta, V. 2001. Structural changes in seed coat morphology during dormancy breaking in some medicinal plants. In: Proceedings of National Seminar on Frontiers of Research and Development in Medicinal Plants. (eds.) Kumar, S., S.A. Hasan, S. Dwivedi, A.K. Kukreja, A. Sharma, A.K. Singh, S. Sharma and R. Tewari. CIMAP, Lucknow, pp. 672673.

Gupta, V., S. Thapliyal and A.K. Singh. 2004. Breaking seed dormancy in Thespesia populnea Soland. ex. Correa.: A wild medicinal tree. Seed Research 32:209-210.

Kassuya, U.A.L, D.F.P. Leite, L.V. De Melo, V.L.G. Rehder and J.B. Calixto. 2005. Antiinflammatory properties of extracts, fractions and lignans isolated from Phyllanthus amarus. Planta Medica 71:721-726.

Khare, C.P. 2007. Indian Medicinal Plants - An Illustrated Dictionary. Springer-Verlag, Berlin, New York, USA.
Mutha, N., M.D. Bohra, V. Burman and L.N. Harsh. 2004. Effect of seed size and pretreatments on germination of Albizia lebbeck (L.) Benth. Indian Jour. Forestry 27:11-14.

Porter, R.H., M. Durell and H.J. Room. 1947. The use of 2, 3, 5- triphenyl tetrazolium chloride as a measure of seed germinability. Plant Physiol. 22:149-159.

Saharan, P., P.K. Kasera and D.D. Chawan. 2001. Seed polymorphism and germination behaviour of Shankhpushpi (Evolvulus alsinoides). Annals Arid Zone 40:97-99.

Salisbury, E.J. 1942. The Reproductive Capacity of Plants. G. Bell and Sons, London.

Sen, D.N. 1977. Environment and Seed Germination of Indian Plants. The Chronica Botanica Co., New Delhi, India.

Tiryaki, I. 2006. Priming and storage of Amaranth seeds: Effects of plant growth regulators on germination performance at low temperature. Seed Sci. and Technol. 34:169-179.

Verma, V. and P.K. Kasera. 2006. Effect of different seed and fertilizer treatments on growth and biomass of Sida cordifolia in semiarid desert region of the country. Jour. Med. and Arom. Pl. Sci. 28:23-26. 